\title{
Beauty and the Beast: The Value of Teaching Fairy Tales to University Students in the 21st Century
}

\author{
Jane Beal \\ Correspondence: Jane Beal, United States. \\ Received: April 5, 2021 Accepted: April 22, 2021 Online Published: April 29, 2021 \\ doi:10.11114/ijecs.v5i1.5207 \\ URL: https://doi.org/10.11114/ijecs.v5i1.5207
}

\begin{abstract}
In this essay, I suggest that fairy tales have particular value for students studying at the university level. Assigning fairy tales allows students to read familiar stories from their childhood and reconsider them from critical perspectives. When teaching a college course on fairy tales, my students and I utilize three essential frameworks for understanding fairy tales, focusing on the psycho-social development and sexual maturation of the human person, feminist critique and the need for gender equality in a patriarchal world, and audience reception and reader responses leading to emotional progress and even spiritual enlightenment. Students primarily familiar with Disney film versions of fairy tales enlarge their understanding of multiple versions of tales, both early modern and contemporary. They become familiar with classic fairy tale writers and collectors, such as Charles Perrault, Madame d'Aulnoy, the Brothers Grimm, Hans Christian Anderson, Oscar Wilde, Andrew Lang, J.R.R. Tolkien, C.S. Lewis, Anne Sexton, Angela Carter, and J.K. Rowling as well as fairy tale scholars like Bruno Bettelheim, Maria Tartar, and Jack Zipes. Their study not only results in a firm grasp of the key aspects of story in general, but in the ability to see connections between the real-world problems of the $21^{\text {st }}$ century - such as poverty, starvation, disease, inequality, child abuse, human trafficking, and abuses of political power, among others - and lessons learned from fairy tales. This essay analyzes "Beauty and the Beast" as a key example of the genre and identifies pedagogical strategies for teaching it.
\end{abstract}

Keywords: Beauty and the Beast, Bruno Bettelheim, Walt Disney, Edward Scissorhands, On Fairy Stories, fairy tale, Maria Tartar, J.R.R. Tolkien, transformation

\section{Introduction}

Fairy tales have enduring power. When American students come to their university studies, they already know many fairy tales, certainly in part because of Walt Disney films that they watched repeatedly throughout their childhood. ${ }^{1}$ This is particularly true at the small, liberal arts college where I teach in southern California, which is within an hour's drive from Disneyland and Disney Studios and which serves thousands of diverse students primarily from our region. Most familiar to my students are classic fairy tales featured in films like "Snow White and the Seven Dwarves" (1937), "Cinderella" (1950, remade 2015), "Sleeping Beauty" (1959, remade as "Maleficent" in 2014), "Little Mermaid" (1989), "Beauty and the Beast" (1998, remade 2017), "The Princess and the Frog," (2009), "Rapunzel" (as "Tangled," 2010), and "Aladdin" (1992, remade 2019). Perhaps students are also somewhat familiar with Hans Christian Andersen's "Snow Queen," upon which "Frozen" is very loosely based (2013). Whatever view one takes of Disney fairy tale films, whether positive or negative, ${ }^{2}$ there can be no doubt that Disney has kept alive a culture of fairy tale telling and re-telling, viewing and re-viewing, that has shaped the imaginations of thousands of children and adults and put a heavy emphasis on the desirability of a happy ending.

Those hard at work in the Walt Disney Studios are not unaware of the cultural critique of their fairy tale films, and in response, they have produced a series of films that provide ironic critique of their past productions. Such self-critiques are evident in "Maleficent," a retelling of "Sleeping Beauty" from the Wicked Witch's point of view; "Enchanted,"

\footnotetext{
${ }^{1}$ See, for example, Sophie McEvoy. (2019). Science Says Watching Disney Characters Die is Good for You for this BRUTAL Reason. Bustle.com. Retrieved on April 21, 2021 from https://www.bustle.com/p/is-watching-disney-films-as-a-child-good-for-you-a-study-reckons-it-could-have-a-massive-i mpact-15582053.//

${ }^{2}$ See Jack Zipes. (2016). Breaking the Disney Spell. In The Classic Fairy Tales, $2^{\text {nd }}$ ed.. ed. Maria Tartar. (Ed.) New York, NY: W.W. Norton. Pp. 502-27.
} 
(2007) and "Into the Woods" (2014). My students tend to be familiar with these films as well, and so they enter our classroom enchanted with fairy tales and critical of them both ethically and aesthetically.

\section{Introducing Students to Fairy Tales}

In my course on "Fairy Tales in Literature and Film," we begin with an introduction to the etymology, definition, and genre of the fairy tale. "Fairy" comes from the Old French and Middle English "fay," meaning "mad, wild, or magic." The term is related to another, "faerië," referring to enchantment and Faerië land itself: the Otherworld. By definition, a fairy tale is a short story with folkloric characters on adventures that involve magic. In seventeenth-century France, Madame d'Aulnoy gave the genre its name, calling these tales "contes de fees," which, when translated into English, means "fairy tales."

The setting, the time when and place where the fairy tale occurs, are rarely specific. Instead, tales happen "once upon a time," often "in a land far, far away." However, the plot follows a quest motif that inevitably makes the characters intersect with the magical otherworld of Faerië. Main characters in fairy tales often undergo a dynamic transformation, in relation to their hopes and fears, wishes or dreams, but may otherwise be surrounded by flat, static characters representing one dimension of human experience or morality. Archetypal human characters are standard in fairy tales: the prince (or knight in shining armor), the princess (or damsel in distress), the good orphan, the wicked stepmother, and so on. Magical creatures abound: fairies, dwarves, goblins, elves, trolls, ogres, giants, gnomes!

The literary style of fairy tales is typically simple, concise, and repetitive, as we might expect of tales that originate in oral tradition, and they are usually chronologically straight-forward: flashbacks are rare. The stories can be surprisingly dark in tone, engaging with issues that range from poverty and starvation, to abandonment and cruelty, to theft and murder. Yet fairy tales tend to end happily. The power of wish-fulfillment fantasy is embedded in the genre.

While we often think of fairy tales as being intended for children, due to the way in which they were collected, revised, and marketed to parents for their children in nineteenth century Europe, England, and America, in fact these stories are not necessarily for children exclusively. In the nineteenth century, fairy tales were often seen as vehicles for fostering children's ability to read and develop as moral beings concurrently. In the twentieth century, Bruno Bettelheim made a strong case, partially based on Jungian psychoanalysis, for the value of fairy tales to children's psychological and social development (Bettelheim, 1976). Before Bettelheim published his influential book, The Uses of Enchantment, J.R.R. Tolkien argued that fairy tales were not exclusively or primarily for children, but rather that adults were part of the intended audience, too, who benefitted as much as, if not more than, children (Tolkien, 1947). Jack Zipes would later argue along similar lines (Zipes, 1979).

With this introduction to the genre of the fairy tale in mind, I invite my students to consider the major writers and collectors of fairy tales who have shaped the western reception of the genre in contemporary times. Charles Perrault, a seventeenth century fairy tale writer, brought us "Cinderella," "Little Red Riding Hood," "Puss in Boots," "Bluebeard," and "Mother Goose." Another seventeenth century French writer, Madame d'Aulnoy, gave us "Goldilocks and Charming" (an early version of the Cinderella story). In the eighteenth century, the Brothers Grimm collected their Kinder und Hausmarchen, or Children's and Household Tales. From them, well-known stories like "Rapunzel," "Rumpelstiltskin, "Snow White, "Hansel and Gretel," and "The Town Musicians of Bremen" come down to us. In the nineteenth century, the extraordinary Danish writer, Hans Christian Andersen, wrote his famous "eventyr" or "adventure" stories, including many of the fairy tales that we know and love: "The Little Mermaid," "The Little Match Girl," "The Princess and the Pea," "The Snow Queen," "The Ugly Duckling," "Thumbelina," and "The Emperor's New Clothes." Influenced by Andersen, Irish writer Oscar Wilde, living in England, also penned a collection of fairy tales.

In Scotland, Andrew Lang collected and published twenty-five books of fairy tales. Twelve of these had covers of a certain color, and so they were known as The Blue Fairy Book (1889), The Red Fairy Book (1890), and so on. Included in the series was a version of 1001 Arabian Nights. A number of middle-class English Victorians had all of these books in their home libraries, and they read them to their children and their families. This established a tradition that was carried on by reading families in the twentieth century. It is interesting to note that both J.R.R. Tolkien and C.S. Lewis read and were greatly influenced by Lang's fairy tale books. The great fantasy worlds of Middle-earth and Narnia owe a debt for at least part of their existence to Andrew Lang (Berman, 2007). Likewise, the Wizarding World of J.K. Rowling is influenced by fairy tales and the antecedents of Narnia and Middle-earth.

\section{An Exemplary Fairy Tale: "Beauty and the Beast"}

We devote the first two weeks of class to studying the seventeenth-century French fairy-tale, "Beauty and the Beast." Using Maria Tartar's Norton anthology, The Classic Fairy Tales, $2^{\text {nd }}$ edition, the students read a variety of versions of the tale from different times and across cultures. Although there are several film adaptations of "Beauty and the Beast," including the Disney cartoon (dir. Gary Trousdale and Kirk Wise, 1991) and Disney live-action remake (dir. Bill 
Conden, 2017) as well as the classic black-and-white film (dir. Jean Cocteau, 1946), I pair the fairy tale reading with a film that has similar themes: "Edward Scissorhands" (dir. Tim Burton, 1990).

We begin by discussing the fairy tale as written by Gabrielle-Suzanne Barbot de Villeneuve (published 1740), in the form of a novella, and as abridged and republished by Jeanne-Marie Leprince de Beaumont, in the form of a short story, which first appeared in Magasin des enfants (1756). The latter version was shared, in English translation, in Andrew Lang's Blue Fairy Book (1889), and it became popular among English readers; we read Lang's version in our class. The story bears considerable resemblance to the Greek myth of "Cupid and Psyche" and the love story itself can be compared to the yearnings present, and interpreted at multiple levels of meaning in Jewish and Christian tradition, in the Song of Songs. ${ }^{3}$

In "Beauty and the Beast," two folktale genres are elided: the beast fable and the fairy tale. As in many examples from Aesop, talking animals are a standard part of beast fables, so it is no surprise that in this tale, the Beast can speak. Of course, this is explained in the fairy tale by the fact that he is a human being who has been enchanted and transformed into a beast.

As in many fairy tales, the female protagonist at first appears as an allegorical character: called Beauty, she stands for beauty. Yet in the French versions of the story, Beauty is not a one-dimensional allegorical personification, but rather a dynamic character. Her loveliness is not only in her appearance, but in her inquisitive mind and innocent heart and genuine moral character. She has a psychological depth that is typically lacking in allegorical figures. In Leprince de Beaumont's version, she dreams dreams that show what is happening within her subconsciously as she struggles to recognize that the prince whose portrait she so admires in the castle is the Beast she talks to everyday, though in disguise, because he is under a spell. She eventually learns not to judge by outward appearances, but rather to value what is hidden and unseen in a man, and so both Beauty and the Beast are rewarded: his humanity is restored, and her desire is fulfilled.

In the course of the story, Beauty grows from being a young girl, firmly attached to her father and brothers and sisters, to a young adult woman ready to leave her family to be married. This trajectory in the female protagonist's development, replete as it is with obstacles and challenges, both within and without, fits the arguments posited by Bruno Bettelheim in The Uses of Enchantment. An audience of children reading this story may find answers to key questions that help with their psychological, social, and sexual maturation as persons. As Bruno Bettelheim has observed in The Uses of Enchantment (1976):

Myths and fairy stories both answer the internal questions: what is the world really like? How am I to live my life in it? How can I truly be myself? The answers given by myths are definite, while the fairy tale is suggestive; its messages may imply solutions but it never spells them out. Fairy tales leave to the child's fantasizing whether and how to apply to himself [or herself] what the story reveals about life and human nature. (p. 45)

Bettelheim's generalization does not hold for all fairy tales, of course, and in the case of Disney's animated "Beauty and the Beast," the messages conveyed to teach children are actually quite explicit, not implied.

\section{Disney's "Beauty and the Beast": Clear Moral Messages}

Because adult audiences in America often think of "cartoons" as entertainment made primarily for children, it is possible to overlook the moral teaching of a Disney film. Yet in the case of "Beauty and the Beast," the prologue that the director adds to the fairy tale is explicitly, morally didactic. The young prince is characterized as "selfish," and because of his unkindness to an old beggar woman, who turns out to be a beautiful enchantress in disguise, he is punished by being transformed into a beast - and all those in his castle undergo transformation as well. Obviously, the moral is not to be selfish and unkind to the poor or elderly.

In Leprince de Beaumont's version, the prince's transformation is depicted as a random act of magic, not a punishment. Disney's animated film, by contrast, shows that there is a cause (selfishness) that leads to an effect (transformation into a beast) that few young children will misunderstand. However, an older child or adult may well question if the punishment corresponds fairly to the offence. As it turns out, in the Disney version of the fairy tale, the prince was only eleven years old when he was punished for his selfishness, for he has been under the enchantment for ten years when he meets Belle, and he knows the spell must be broken by the time he is twenty-one. This youthfulness, and the seriousness of the Beast's punishment - which in Disney's version is made all the more extreme by the fact that the Beast must find someone who will love him despite his hideous outward appearance before his twenty-first birthday or he will die - sets

${ }^{3}$ The lover and beloved of the Song of Songs have traditionally been interpreted as representative of God and Israel, Christ and the Church, and the Divine Love and the human soul. Medieval Christian allegorical interpretation of the Cupid and Psyche myth saw it in terms similar to the third interpretation of the Song of Songs. 
up the audience to sympathize with the Beast in his loneliness and distress.

Our sympathies are limited, however, when the Disney film portrays the Beast struggling with his temper. He is chastised for this by Mrs. Potts, an older serving woman who has been transformed into a teapot and whose children have been transformed into teacups. "Temper, temper!" she says to him when he roars at the frightened (yet bravely defiant) Belle ("Beauty and the Beast," 1991). It is clear that the Beast has a lot to learn.

In terms of his character, he must become less selfish and angry. A stained-glass window of the Beast's castle reinforces this message through a medieval-like, Latin inscription: "vincit qui se vincit," which, when translated, reads "he conquers who conquers himself." "While most American children will not be able to read or translate Latin, the unknown words may provoke curiosity, and perhaps a question that prompts a parent's Google search, which can lead to a discussion of the theme of moral character development in the story.

In the film, the Beast wants Belle to love him so that his life may be saved and his humanity restored. Yet at a much more profound level, he must learn to love in a self-sacrificing - not selfish - way. He has been preoccupied with his own best interest (understandably so!), but what is in Belle's best interest? When Belle sees her father in a magic mirror, and realizes he is sick and caught in a snowstorm, she begs the Beast to let her go and care for him. The Beast agrees, though he realizes she may not return, and he may die without her love. With his decision to let Belle go, he is finally conquering his selfishness and temper, though he knows the last rose petal may fall from the enchanted rose he guards so carefully, and, in that moment, he will die.

Because this is a fairy tale, and a Disney version at that, the Beast's self-sacrificing love for Belle is rewarded with a happy ending. The Beast does die in the film, and Belle appears to return too late to save him, but the rain and Belle's tears baptize his body in order to effect a magical resurrection. The animated film depicts the Beast's body rising in swirling clothes of red and white shot through with rays of light, a clear visual and symbolic allusion to iconic representations of Christ's Resurrection. The Beast awakens from the dead, a human prince again, to be lovingly embraced by Belle.

\section{Cross-Cultural Versions of the Fairy Tale: Similar Motifs, Different Messages}

Other versions of this fairy tale from around the world, gathered together in Maria Tartar's anthology, The Classic Fairy Tales, have the same motif of a beast (or creature) transformed back into a human, but they convey different messages. Leprince de Beaumont stresses that Beauty must learn not to judge by outward appearances, and the Disney animated film emphasizes that the Beast must conquer his baser impulses and act from his higher moral nature. But some of the cross-cultural folktales from Tartar's anthology are not as clearly, morally didactic, and they have much less optimism in their conclusions. By exploring these darker tales, students discover other moral issues germane to the human condition and begin to make connections to real-world problems of the $21^{\text {st }}$ century.

In the first week of my class on "Fairy Tales," after our discussion of Leprince de Beaumont's "Beauty and the Beast" with reference to the Disney film the students already know so well, I assign each of the different versions of the fairy tale from The Classic Fairy Tales anthology to individual students or sets of partners. For the second week, the students are responsible for writing a short response paper in which they summarize the tale and compare it to the more familiar, seventeenth-century French version. They must also analyze the fairy tale in terms of psychological criticism with reference to Bettelheim's arguments in The Uses of Enchantment, or feminist criticism with reference to the ideas of Maria Tartar, Angela Carter or Anne Sexton, or reader response / audience reception with reference to concepts from J.R.R. Tolkien's “On Fairy Stories." Students present their summary-analyses in the next class. The discussion that follows is lively.

One version, "The Frog King" which was collected by the Brothers Grimm, contains the transformation motif. A frog asks a young princess to promise to let him eat off her golden plate and sleep in her bed if he fetches her lost ball for her. The princess makes the promise, and much to her chagrin, the frog expects her to keep it. When she runs off, he follows, and he knocks on the door of her father's palace. When it opens, he explains the bargain they struck. Though the princess is reluctant, her father insists she must keep her promises. So she allows the frog to eat off of her plate, Later, he expects to sleep in her bed. When he hops up, she is so disgusted that she throws him against the wall, where he transforms into a handsome prince (Tartar, 2016). Is this what happily ever after looks like?

The students easily see Bettelheim's theories of the didactic function of fairy tales for children at work in this story. The moral of the story is clear: if we give our word, we must keep our promises. At the same time, there is an implied warning in the story: we must not give our word too rashly! Was retrieving the ball really worth promising in exchange for intimacy at suppertime and bedtime with a frog? Probably not. Yet promise-keeping is rewarded with

\footnotetext{
${ }^{4}$ This phrase also may be found painted on a wall in the Rose Tavern at Disneyland.
} 
wish-fulfillment in the "happy" ending when the frog is transformed to a prince who is a much more suitable match for the princess than an amphibian. The psycho-social development of a child benefits if the child thinks through the moral and social messages conveyed by the fairy tale.

Those students who choose a feminist analysis of this fairy tale are a bit sharper in their critique of it. Clearly, the patriarchy is at work! A male frog tricks an innocent girl into getting something he wants, but she doesn't. She is forced to give up her childhood innocence, symbolized by the ball she lost at playtime, to grow up much faster than she is ready to do because her father (the patriarch) enforces the deal - despite its apparent inequity. The frog is selfishly intrusive and without respect for the princess's personal boundaries; indeed, the amphibian in her bed has phallic implications that are hard to miss. And how is it a happy ending simply to get married to a frog who has transformed into a prince? The princess doesn't even know him! How underwhelming.

Furthermore, this princess is not like Beauty, who is smart (think of all of her beloved books in both the Leprince version and the Disney film!), beautiful (inside and out), and kind. This princess is immature, and it is not clear that she has particularly changed or matured when she hurls the frog against the wall. The prince's outward change in appearance seems shallow compared to "Beauty and the Beast," in which the inner transformation made possible through self-sacrificing love is a key theme. The motif is the same - transformation from a creature to a man - but the message is clearly different.

My feminist readers have still more to chew on in Angela Carter's short story, "The Tiger's Bride." It begins with a frankly frightening opening statement: "My father lost me to the Beast at cards" (Carter, 1979, p. 92). Angela Carter's contemporary English version highlights the injustice of a poor man selling his daughter to another to pay his own debt, a reality strongly implied in traditional versions of the fairy tale as well, but inescapable in Carter's version. Behind her plot lurks the specter of human trafficking. As a class, we discuss again the seventeenth-century French version, in which the father takes a rose from the Beast's castle-gardens and is asked to pay for it by sending his daughter back to the Beast. Is this not a grave social injustice, one perpetuated in times past between two different classes, the noble rich and the peasant poor? Disturbingly, it also happens all too often today all around the world.

In both the Leprince and Disney versions, emphasis is placed on the fact that Beauty chooses to exchange places with her father because she loves him and is willing to sacrifice her freedom to save him. Her freedom only is at stake. There is no actual threat to her life or her virginity in these versions as the Beast intends to keep her captive only in hopes that she will one day love him of her own free will. In Carter's version, that is simply not the case. Her Beauty is objectified from the beginning: offered, bought, and sold.

Carter makes other changes, too: strikingly, the Beast is a tiger dressed up as a man, who later reveals his true identity as a tiger to the girl. The theme of self-revelation, of the connection between nakedness and vulnerability, is emphasized in the story. In the end, the Beast is not transformed into a man, but rather the girl is transformed into a tiger when she accepts the Beast for who he is.

The students notice that Carter's feminist message here is a critique of the objectification of human women at the hands of the patriarchy. Carter seems to suggest instead the desirability of finding common ground with men who may be on the outside of social acceptance and thus alienated from some patriarchal norms. Beauty's apparent transformation into a tiger herself seems to be a feminist parable about a woman finding her own inner empowerment. That it is achieved only because the Beast, the tiger, licks off her human skin to reveal her "beautiful fur" (Carter, 1979, p. 109) may undercut the message of female power discovered, but Carter's ambivalent ending is no doubt deliberately constructed to provoke further thought.

The folktale "Urashima the Fisherman" contains the transformation motif as well. ${ }^{5}$ In this case, a Japanese fisherman encounters a five-colored turtle who transforms not only into a woman, but a divinity who takes him to her Eternal Mountain. There they dwell in bliss for three years until he wishes to return to visit his parents back at home. They talk about this homesickness sadly until they agree to separate so he can visit. When he does, he finds that three centuries have passed. He carries with him a box that his divine lover told him to hold tightly when he wished to return to her, but not to open. Sadly, Urashima forgets his immortal lover's command and opens the box, whereupon he sees her "fragrant form" (Tartar, 2016, p. 112) drift upwards and disappear.

\footnotetext{
${ }^{5}$ My students and I discuss the version given in Maria Tartar's anthology, The Classic Fairy Tales, but it should be noted that there are many versions of this tale in Japanese literature. In some, instead of going to the Eternal Mountain, he descends to the Dragon Palace under the ocean waves. The turtle takes him here, but she is only the servant of the princess, with whom Urashima Taro falls in love. In other Japanese versions of the tale, when the man returns home, he is transformed into an old man - or a crane. This tale dates back to the $8^{\text {th }}$ century.
} 
Then a last song burst from him as he struggled with his loss, "My love, when after a night of longing, day dawns and I stand at my open door, I hear far off waves breaking on the shores of your paradise." If only he had not opened the jeweled box, people have said since, he could have been with her again. But the clouds hid her paradise from him and left him with nothing but his grief. (Tartar, 2016, p. 112-13)

Here the transformation motif is linked strongly with the discovery of love and the subsequent losing of it, a loss which plunges Urashima into profound grief but, at the same time, stirs him to create poetry and song.

This poignant feeling about love and loss and inspiration is viewed, by J.R.R. Tolkien in "On Fairy Stories" and his related short story, "The Smith of Wootton Major," as part and parcel of the experience of a human being entering the world of Faerië. The message of "Urashima the Fisherman" is much more emotional than moral. Love may be tied to loss. Growing up to marry may involve the loss of one's parents and family of origin over time. Giving up divine (romantic) love for human (parental) love is hardly advisable. But if it happens, because of the demands of the human heart, then getting in touch with the creative spirit within and making poetry and song about the loss of love is one way to move through the grief. These are not messages about right and wrong, but about lost love and the desire to be healed from pain.

In his essay, "On Fairy Stories," Tolkien sees the function of the fairy tale as facilitating such healing, specifically through Fantasy, Escape, Recovery, and Consolation (Tolkien, 1947). For Tolkien, imagination is the mental power of image-making, but Fantasy is the sub-creation of a secondary world with the inner consistency of reality that deeply engages readers in the wonder and strangeness of Faërie. According to Tolkien, Escape is not the escape of a deserter, but of the prisoner from reality. Recovery, Tolkien writes, is about the recovery of a "clear view" of reality. By stepping outside of reality, into a fairy-tale world, and then back again, readers are able to have a significant shift in perspective. Consolation comes to the reader through the happy ending.

For Tolkien, the happy ending is essential to the genre. Without it, the story isn't a fairy tale. With it, the fairy story has the power to transform the reader. He even aligns the "happy ending" of fairy stories with the Gospel, the "good news" of his Christian faith, which taught him that salvation leads to the redemptive culmination of time in Heaven for all believers.

For Tolkien, such redemptive culmination was necessary because of the sin and sorrow of this life. As a survivor of World War I and World War II, who served as a soldier and signals officer on the battlefield and as a warden on the home front in Britain, Tolkien sought to bring healing to himself through his own writings, and then he offered it to readers of his works, The Hobbit and The Lord of the Rings. In "On Fairy-Stories," he offers his theories to readers of fantasy and fairy tale stories generally.

My students inevitably find Tolkien's language for describing the effects of fairy tales on readers - Fantasy, Escape, Recovery, and Consolation - helpful for understanding various reader responses to the genre, but especially the peculiar quality of fairy tales that can elicit our grief, inspire us to use our imaginations, and bring about a sense of inner healing.

\section{6. "Edward Scissorhands": Beauty and the Beast Redux}

When I teach "Beauty and the Beast," I pair it with "Edward Scissorhands" (dir. Tim Burton, 1990), which I ask my students to watch and be prepared to compare to the fairy tale. "Edward Scissorhands" is itself a fairy-tale film. Metacritically, it gestures to its own fairy tale status in the opening, when a grandmother is depicted as putting her granddaughter to bed by telling her a story to explain snowfall in their little neighborhood. She says it comes from the man who lives in the mansion on the hill high above the town. Viewers watch as the camera pans past the grandmother's wrinkled face to the window, where we see the tall, dark, Gothic mansion - like a castle or a ruined abbey - through falling snowflakes. Then the shot moves through the window toward the castle and the story begins.

Edward is made by a human inventor, who dies before he has the chance to complete him. Instead of real hands, Edward has scissor blades for fingers. Indeed, it is just in the moment when his inventor presents Edward with hands that the inventor has a heart attack, and Edward accidentally cuts to shreds the precious gift of hands with his scissor blades. So after that, he lives alone in the dark mansion.

His situation that evokes a nineteenth-century Gothic horror fiction feeling and makes obvious allusions to Mary Shelley's Frankenstein. ${ }^{6}$ This is not the only literary allusion included in the flashback to Edward's early life, for the camera pans above a bed made of straw that Edward sleeps in, and above his sleeping place (which could be compared to large manger) is pinned a picture of the Virgin Mary holding baby Jesus, which is hung beside other newspaper

${ }^{6}$ The director was also influenced by such classic horror films as "The Hunchback of Notre Dame" (1923), "The Phantom of the Opera" (1925), "Frankenstein" (1931), "Creature from the Black Lagoon" (1954), and "King Kong (1933) as well. 
clippings. The image conveys the sense that Edward may be taking comfort in the maternal idea of Mary. Edward himself may even be a type of Christ-child, whose subsequent actions have potentially salvific effects on the world into which he is drawn down.

It is at the castle that Peg Boggs, the neighborhood's local Avon sales representative, discovers Edward when she goes selling make-up door-to-door and decides to take him home. Peg seems to be motivated by genuine, maternal love when she opts to bring Edward home as a foster child. Yet Edward has never experienced a mother or, for that matter, a family. He meets Bill, Peg's husband, and their son, Kevin, and finally Kim, their teenaged daughter, with whom he quickly falls in love. This, of course, presents an inverted parallel to the fairy-tale, "Beauty and the Beast." Edward is the Beast, because of his scissor-hands, and Kim is the Beauty. Yet instead of Beauty being brought to the Beast in his castle, the Beast is brought to her - and revealed to be quite vulnerable in a middle-class, suburban neighborhood.

Edward gains acceptance in the community by making good use of his scissor-hands. First, he uses them to cut hedges to make topiaries, then dogs' hair to groom them, and finally, women's hair to style it. In all this, he is demonstrating an intense creativity - the creativity of an artist. It appears, at one point, that he will be launched into adult responsibility and independence through his artistic talent when a woman from the neighborhood, Joyce, goes out with him to try to find a location to open a salon. Once indoors, however, Joyce attempts to get him to have sex with her. Edward runs away. Joyce later gossips with women in the neighborhood and says he attempted to rape her. Edward's acceptability in the neighborhood takes a sudden downturn.

Edward has other difficulties to face, and each one builds on the next, until the character reaches a breaking point. From the beginning of the story, he struggles not to cut his own face accidentally. Peg tries to cover up the facial cuts with her Avon make-up, but this hardly solves the underlying problem. Edward also punctures Kim's waterbed when he is sleeping in it while she is gone camping. At the family dinner table, he struggles to eat properly because he cannot hold the usual utensils.

These problems are minor, however, compared to being talked into breaking-and-entering by Kim's jealous boyfriend, Jim, who wants him to help to steal a van from Jim's parents. Edward agrees and is subsequently arrested. It turns out his moral sense of right and wrong isn't especially strong or clear, and he agreed to assist in the theft because he loves Kim and she asked for his help - although Kim herself was peer-pressured into the escapade by her boyfriend. Local society - including the police and a judge - heaps even more shame on Edward.

But on Christmas Eve, despite his hardships, Edward uses his scissor-hands to carve an ice sculpture of Kim. The ice shavings are like snow in the air, and these swirl around Kim, who dances in them with delight. Then Kim's boyfriend Jim arrives, calling out to Edward and startling him, which causes Edward to cut Kim's hand accidentally. Jim blames Edward and says he did it on purpose. Kim, tired of Jim and his jealousy, breaks up with him, and Jim leaves irate.

Then, that very night, an unfortunate accident occurs. Kevin, Kim's younger brother, runs in front of a van, which Jim, drunk, is driving. Edward pushes Kevin out of the way, saving his life, but when they both fall to the ground on the other side of the street, Edward accidentally cuts the boy. Neighbors failed to see that Edward saved the child from being hit by the van but pay close attention to the accidental cutting - and blame Edward as if this is deliberate. Jim gets out of van and attacks Edward, who defends himself and cuts Jim's arm. Then Edward runs away in the direction of his inventor's castle.

Both Kim and Jim separately go after him - Kim to comfort him and Jim to continue his attack. The three face one another on the second story of the castle, not far from Edward's old straw bed. When Edward defends himself and Kim from Jim, he ends up stabbing Jim in the stomach and then pushing him from the second story of the castle. So Jim falls to his death, which is both shocking and macabre. Then Kim kisses Edward, and tells him she loves him, before leaving him. Edward hides while Kim goes down to tell the neighbors, who have come streaming (albeit with some hesitancy) into the mansion gardens, that Edward and Jim have killed each other. Somehow, they believe her.

So the story ends with images of Edward still cutting topiaries in the gardens and making sculptures on the second floor of many different kinds of people, including the human children he saw at play in the neighborhood when he lived there with the Boggs family. As the Beast, he is never fully transformed into a human outwardly. Inwardly, however, he is transformed and enriched as an artist.

At the end of the movie, it is striking that a window of the Gothic mansion has the shape of a cross preserved in it that overlooks the garden and a special topiary cut into the shape of an open, human hand. The camera lingers poignantly on the twinned symbolism of the Cross and the human hand for a moment at the end of the film before the credits roll. Clearly, the Cross, a symbol of salvation and redemption, looks out over the hand below it even while the hand reaches out, open, to the Cross in the window above. Apparently, Edward cut that topiary as an artist's expression of unfulfilled desire: it is the human hand he does not have but wishes he could have. He makes all his works of art with imperfect 
scissor-hands.

\section{7. "Edward Scissorhands": A Happy Ending?}

This is not the happy ending that fairy tales might lead my students to expect: the one in which the Beast is physically transformed and marries Beauty. Instead, the Beast learns to use the very things that makes him beastly in the eyes of others - his scissor-hands - to create works of art and beauty. Meanwhile, the human Beauty marries someone else, and her child has a child, and she becomes a grandmother telling the story of her love for Edward. She, too, is an artist: a storyteller who makes art out of words. Edward himself is not physically, but spiritually transformed. Kim is transformed, too, by love and a long life, so that she becomes a wise old woman. This, too, is a happy ending, though it sometimes takes my students a bit of time and discussion to see it that way.

In our discussion, the students apply ideas from The Uses of Enchantment to the film. They conclude that "Edward Scissorhands" certainly has to do with moving from childhood to adulthood and maturing psychologically, sexually, and socially (Bettelheim, 1976). This can be seen in the flashbacks to Edward's "childhood," as his inventor assembled him, and through the main plot of the story, which is a kind of bildungsroman about Edward's life-journey. Kim, too, is shown maturing from a teenager to a grandmother. An awakening to love and desire between Edward and Kim plays a key role in the maturation of both of these characters.

The students also reflect back on Angela Carter's story, "The Tiger's Bride," and make feminist critiques of the problems of patriarchy in the film. On the one hand, the Tiger and Edward Scissorhands could be considered types of the "feminine man," the non-alpha male who shares experiences of oppression in common with women in patriarchal societies (Tartar, 2016). Edward is victimized in several relationships with other people, including his inventor, the neighbor Joyce, and Kim's boyfriend Jim, as well as the neighborhood generally. Yet he does not take on the role of victimizer himself. Instead, he remains gentle, as his interactions with Kim demonstrate.

Kim certainly has her own independent will, but she is both verbally and physically coerced by her boyfriend Jim. In one instance, she is literally picked up and carried away from Jim's parents' home by Jim when she wants to go back in to get Edward, who has been locked inside by the alarm system. Edward is ultimately left to take the blame for breaking and entering as the petite Beauty, Kim, cannot physically overcome Jim.

The strong women in the story - from the iconic Mother Mary to foster-mother Peg Boggs to Kim herself, who is a storytelling grandmother at both the beginning and the end of the film - certainly resist patriarchal control. Yet they are also subject to being undermined by the systemic gender prejudices represented in the suburban social scene of which they are a part. Their efforts are portrayed as admirable, and more effective than those of the inventor in the dark manse or Peg's husband, Bill, yet they do not ultimately free Edward from the negative consequences of other people's actions nor do they successfully free themselves from the restrictions of society on them and around them.

When we come at last to J.R.R. Tolkien's emphasis on the importance of the "happy ending" for a fairy tale to be considered a fairy tale (Tolkien, 1947), my students enter an inevitable debate. Traditionally, in versions of "Beauty and the Beast" from around the world, the transformation is present and ultimately leads to the marriage of two lovers. Yet these two key aspects are missing from "Edward Scissorhands." So the question then arises as to whether or not the non-traditional ending of the film is "happy."

At first, the students think not. Their own feelings of disappointment and sorrow, evoked through empathizing with the suffering of Edward and Kim in their unjust suburban society, are their moral guides to this conclusion. Yet as we discuss the ending - how two artists are being creative in their own spheres, making sculptures and telling stories, one in a mansion and the other at home with her granddaughter - the students re-consider. Is there some element of redemption present here? Some of my students are willing to concede that this kind of ending might be happy, too, albeit not as a "wish fulfillment fantasy" that other fairy tales grant.

\section{The Value of Teaching Fairy Tales: Making Connections to Real-World Problems of the $21^{\text {st }}$ Century}

My course, "Fairy Tales," continues for several more weeks after the initial two are devoted to the theme of "love and transformation" in "Beauty and the Beast." My students and I consider additional themes and fairy tales, including:

- power and negotiation in "Aladdin and the Wonderful Lamp" and Disney's two, filmic retellings (dir. Ron Clements and John Musker, 1992 and Guy Ritchie, 2019)

- freedom and limitation in "Rapunzel” and Disney's "Tangled" (dir. Byron Howard and Nathan Greno, 2010)

- death and magic in "Jack and the Beanstalk" and J.K. Rowling's "Harry Potter and the Chamber of Secrets" (dir. Chris Columbus, 2002) with reference to Rowling's folktale, "Death and the Three Brothers"

- longing and self-sacrifice in "The Little Mermaid" and "Splash" (dir. Ron Howard, 1984) 
- corruption and redemption in "The Snow Queen" and C.S. Lewis's "Narnia: The Lion, the Witch, and the Wardrobe" (dir. Andrew Adamson, dir. 2005)

In each case, we consider the fairy tales in terms of the three different paradigms for interpretation - psychological, feminist, and reader response / audience reception - and consider what different messages are conveyed to different cultures: the cultures in which the fairy-tale originated and the cultures for which they were adapted in film.

The students are also empowered to do their own, completely independent analyses in group presentations on:

- "Little Red Riding Hood" and "Hoodwinked" (dir. Cory Edwards, 2005)

- "Hansel and Gretel" and "Hansel and Gretel: Warriors of Witchcraft" (dir. David DeCocteau, 2012)

- "Snow White" and "Labyrinth" (dir. Jim Henson, 1986) or "Enchanted" (dir. Adam Shankman and Kevin Lima, 2007)

- "Sleeping Beauty" and "Maleficent" (dir. Robert Stromberg, 2014)

- "Cinderella" and "Ever After" (dir. Andy Tennant, 1998)

Our discussions of these classic fairy tales inevitably lead us to consider connections between the stories and real-world problems of the $21^{\text {st }}$ century. In "Beauty and the Beast" and "Rapunzel," there are dark, symbolic hints of how poverty may drive a father to sell his own child to pay his debts. This is human trafficking, a world-wide problem, exacerbated when the rich and the poor living in close proximity to one another.

In the frame-story of the 1001 Arabian Nights, the wise queen, Scheherazade, tells a suspenseful story every night to the Sultan to keep herself and the other women of the kingdom alive - despite the Sultan's practice of killing his brides after marrying them to prevent their potential infidelity. As readers, we can clearly see horrifying instances of violence against all women simply because they are women, with faithless and faithful women being treated in the same unjust manner simply because of their sex. This theme is echoed in "Little Red Riding Hood," where the wolf in Red's grandmother's bed may very well stand for threat of sexual violence that can take place within a blood-related family. As a class, we discuss how 1 in 3 girls and 1 in 6 boys is sexually abused before age 18 in America today.

Issues of poverty and starvation are certainly present in "Jack and the Beanstalk" and "Hansel and Gretel." Following the death of his father, Jack and his widowed mother live in poverty that renders them both intensely vulnerable. In a related story, following the marriage of their father to their wicked stepmother (who, in original German versions, was simply their selfish mother), Hansel and Gretel are living in poverty with their parents and starving. The lack of food leads their parents to abandon them in the woods, who believe they only have enough for themselves and cannot continue to feed their own children. Hansel and Gretel make their way back home a few times, but eventually, are lost in the trees and captured by a cannibalistic witch. As in times past, so today: poverty and food insecurity or food scarcity, which can lead to starvation, regularly devastate people in developing nations of the world. 690 million people are under-nourished globally. ${ }^{7}$ Conflict and war exacerbates the issue of hunger and malnourishment for children everywhere.

Abuses of political power, already seen in the frame-story of 1001 Arabian Nights, emerge again in "The Snow Queen" and "Narnia." In these stories, both the Snow Queen and the White Witch exploit and torment children. They rule their kingdoms with an iron fist, not for the good of those they rule but rather primarily for themselves and their own pleasure. Many of my Hispanic students, already politically aware, make keenly perceptive observations about "rulers" in our own world who allow children to be separated from their parents and kept in holding facilities on the U.S.-Mexico border.

As a result of our discussions, students gain the ability to see connections between the real-world problems of the $21^{\text {st }}$ century, such as poverty, starvation, disease, inequality, child abuse, human trafficking, and abuses of political power, among others. But we do not stop there. We talk about real-world solutions to these problems as well. We discuss what governments, NGOs, and ordinary people are doing to step up and stop abuses. I share with my students my own past work in prevention, intervention, and restoration efforts for victims of human trafficking in Chicago, Moldova, and Ghana, West Africa, and my commitment to serving as a volunteer midwife in impoverished, over-crowded urban areas in the Philippine Islands, Southeast Asia and remote, rural areas in Uganda, East Africa. Every person can make a difference to other people who suffering from world-wide problems, and people who work together in teams can make an even bigger difference for a greater number of people.

We also discuss what fairy tales may really be teaching children and adult readers. When children in these stories suffer,

\footnotetext{
7 See "World Hunger: Facts and Statistics." (2021). Action Against Hunger - USA. Retrieved on April 21, 2021 from https://www.actionagainsthunger.org/world-hunger-facts-statistics.
} 
and mature through their trials and tribulations, they often turn the tide on their oppressors and abusers. The reversal of fortune is achieved both by magic and by grit. Fairy tales like these empower both children and adults who hear them to strive for something more: a happy ending in their own lives.

\section{Conclusions}

Our class culminates in a final creative project on fairy tales. Students may write a narrative poem or short story re-telling a fairy-tale. I give students examples of my own for them to consider: my narrative poem told in seven sequential sonnets, "Scheherazade Invents the Princess of China" (Beal, 2009a) adapted from tales in 1001 Arabian Nights, and my fictional short story, "Alice and the Cornstalk" (Beal, 2009b), inspired by "Jack and the Beanstalk." Students may choose to write a traditional, literary analysis essay on a fairy tale and its adaptations. I share with them my blog post "Girl-Sampson: Reflection on Disney's Rapunzel" (Beal, 2011) as a model. I also give students the option of creating visual art - a drawing, painting, photograph or collage - inspired by a fairy tale, which they explain in a written commentary. I show them my book of art collages, Fairy-Tale, which was inspired by a visit to the fairy-tale town of Solveng in southern California and the Danish fairy-tale teller Hans Christian Andersen. Some brave students go beyond these options to create recordings of readings of fairy tales, or related songs, or short film adaptations of the fairy tales. I never cease to feel amazed at the creativity of my students and the way that fairy tales inspire them.

In all, this course demonstrates the value of teaching and learning about fairy tales at the university level. My students and I re-read classic fairy tales, like "Beauty and the Beast," "Aladdin and the Wonderful Lamp," and "Rapunzel" (and many more), and together, we reconsider them from critical perspectives. My students and I utilize three essential frameworks for understanding fairy tales, focusing on the psycho-social development and sexual maturation of the human person (Bettelheim, 1976), feminist critique and the need for gender equality in a patriarchal world (Tartar, 2016; Carter, 1979; Sexton, 1971), and audience reception and reader responses leading to emotional progress and even spiritual enlightenment (Tolkien, 1947).

Students primarily familiar with Disney film versions of fairy tales enlarge their understanding of multiple versions of tales, both early modern and contemporary. They become familiar with classic fairy tale writers and collectors, such as Charles Perrault, Madame d'Aulnoy, the Brothers Grimm, Hans Christian Anderson, Oscar Wilde, Andrew Lang, J.R.R. Tolkien, C.S. Lewis, Anne Sexton, Angela Carter, and J.K. Rowling as well as fairy tale scholars like Bruno Bettelheim, Maria Tartar, and Jack Zipes. Their study not only results in a firm grasp of the key aspects of story in general, but in the ability to see connections between the real-world problems of the $21^{\text {st }}$ century - such as poverty, starvation, disease, inequality, child abuse, human trafficking, and abuses of political power, among others - in terms of lessons learned from fairy tales.

\section{Acknowledgements}

I thank Nina Howard for inviting me to submit this essay to The International Journal of English and Cultural Studies and the anonymous peer reviewers who helped me to improve it with corrections, suggestions, and encouragement. I also express my sincere appreciation to Dr. Donna Reed, the senior lecturer in Comparative Literature at the University of California, Davis for whom I worked as a teaching assistant for a course called "Fables, Parables, and Fairy Tales" when I was a graduate student many years ago. She taught me so much! Now as a professor, most of all, I thank my students, who inspired me to offer this course on fairy tales to give them a happy ending at least once every other week while we met remotely via Zoom during the coronavirus pandemic.

\section{References}

Adamson, A. (2005). Narnia: The lion, the witch, and the wardrobe. United States: Walt Disney Studios.

Arnold, J. (1954). Creature from the black lagoon. United States: Universal Studios.

Barbot de Villeneuve, Gabrielle-Suzanne. (1740, repr. 1745). La Belle et le bête. In La jeune americaine ou les contes marins. Paris: A La Haye / Chez Merigot.

Beal, J. (2009a). Scheherazade invents the princess of China. In Magical Poems for Girls. Raleigh, N.C. and London: Lulu Press.

Beal, J. (2009b.). Alice and the cornstalk. In Eight Stories from Undiscovered Countries. Raleigh, N.C. and London: Lulu Press.

Beal, J. (2011). Girl-Sampson: Reflections on Disney's Rapunzel. The Poetry Place. Retrieved from https://thepoetryplace.wordpress.com/2011/04/

Berman, R. (2007). Tolkien as a child of The Green Fairy Book. Mythlore: A Journal of J. R. R. Tolkien, C.S. Lewis, Charles Williams, and Mythopoeic Literature: 26(1), Article 9. Retrieved from https://dc.swosu.edu/mythlore/vol26/iss1/9 
Bettelheim, B. (1976). The uses of enchantment: The meaning and importance of fairy tales. New York, N.Y.: Thames \& Hudson.

Branagh, K. (2015). Cinderella. United States: Walt Disney Studios.

Burton, T. (1990). Edward Scissorhands. United States: $20^{\text {th }}$ Century Fox Studios.

Carter, A. (1979). The bloody chamber. London: Gollancz.

Carter, A. (2016). The tiger's bride. In The Classic fairy tales. Maria Tartar. (Ed.) (2016). New York, N.Y.: W.W. Norton and Company.

Chaney, L. (1925). The phantom of the opera. United States: Jewel Productions with Universal Studios.

Clements, R., \& John, M. (1992). Aladdin. United States: Walt Disney Studios.

Columbus, C. (2002). Harry Potter and the chamber of secrets. United States: Universal Studios.

Conden, B. (2017). Beauty and the beast. United States: Walt Disney Studios.

DeCocteau, D. (2012). Hansel and Gretel: Warriors of witchcraft. United States: Lionsgate Studios.

Edwards, C. (2005). Hoodwinked. United States: Weinstein Company.

Geronimi, C. (1950). Cinderella. United States: Walt Disney Studios.

Geronimi, C. (1959). Sleeping beauty. United States: Walt Disney Studios.

Hand, D. (1937). Snow white and the seven dwarfs. United States: Walt Disney Studios.

Henson, J. (1986). Labyrinth. United States: Henson Associates, Inc. and Lucasfilm Ltd. With Tri-Star Pictures, Columbia, and Warner Distributors.

Howard, B., \& Nathan, G. (2010). Tangled. United States: Walt Disney Studios.

Lang, A. (1889). The blue fairy book. London: Longmans, Green, and Company.

Lang, A. (1890). The red fairy book. London: Longmans, Green, and Company.

Lee, J., \& Chris, B. (2013). Frozen. United States: Walt Disney Studios.

Leprince de Beaumont, J. M. (1756). Beauty and the beast. In Magasin des enfants.

Marshall, R. (2014). Into the woods. United States: Walt Disney Studios.

McEvoy, S. (2019). Science says watching Disney characters die is good for you for this BRUTAL reason. Bustle.com. $\begin{array}{lllll}\text { Retrieved } & \text { on } & \text { April } & 21, & \text { from }\end{array}$ https://www.bustle.com/p/is-watching-disney-films-as-a-child-good-for-you-a-study-reckons-it-could-have-a-mass ive-impact-15582053.//

Merian, C. C., \& Ernest, B. S. (1933). King Kong. United States: Radio Pictures.

Musker, J., \& Howard, A. (1989). Little mermaid. United States: Walt Disney Studios.

Musker, J., \& Ron, C. (2009). The princess and the frog. United States: Walt Disney Studios.

Ritchie, G. (2019). Aladdin. United States: Walt Disney Studios.

Rowling, J. K. (2007). Death and the Three Brothers. In Harry Potter and the Deathly Hallows. Bloomsbury, Scholastic, and Raincoast.

Sexton, A. (1971). Transformations. New York, N.Y.: Houghton Mifflin Harcourt Publishing.

Shankman, A., \& Kevin, L. (2007). Enchanted. United States: Walt Disney Studios.

Shelley, M. (1818). Frankenstein or the Modern Prometheus. $1^{\text {st }}$ Ed. London: Lackington, Hughes, Harding, Mayor, and Jones.

Stromberg, R. (2014). Maleficent. United States: Walt Disney Studios.

Tartar, M. (2016). The classic fairy tales. $2^{\text {nd }}$ ed. New York, N.Y.: W.W. Norton \& Company.

Tennant, A. (1998). Ever after. United States: $20^{\text {th }}$ Century Fox Studios.

The frog king. (2016). In The classic fairy tales. Maria Tartar. (Ed.) (2016). New York, N.Y.: W.W. Norton and Company.

Tolkien, J. R. R. (1947). On fairy-stories. In Essays presented to Charles Williams. C.S. Lewis. (Ed.) Oxford: Oxford University Press. 
Tolkien, J. R. R. (1967, repr. 1997, 1998, 2002, 2008, 2009, 2021). The smith of Wootton Major. In Tales from the Perilous Realm. London: Allen \& Unwin and New York: HarperCollins.

Trousdale, G., \& Kirk, W. (1991). Beauty and the beast. United States: Walt Disney Studios.

Urashima the fisherman. (2016). In The Classic Fairy Tales. Maria Tartar. (Ed.) (2016). New York, N.Y.: W.W. Norton and Company.

Whale, F. (1931). Frankenstein. United States: Universal Pictures.

World hunger: facts and statistics. (2021). Action Against Hunger - USA. Retrieved on April 21, 2021 from https://www.actionagainsthunger.org/world-hunger-facts-statistics

Worsley, W. (1923). The hunchback of Notre Dame. United States: Universal Studios.

Zipes, J. (1979, repr. 2002). Breaking the spell: Radical theories of folk and fairy tales. Lexington, K.Y.: University Press of Kentucky.

Zipes, J. (2016). Breaking the Disney spell. In The classic fairy tales, $2^{\text {nd }}$ ed.. Maria Tartar (Ed.) New York, NY: W.W. Norton and Company, Pp. 502-527. 


\section{Appendix}

\section{Fairy Tale Response Papers:}

\section{Posts and Peer Responses}

Length: apx. 500 words each

Format: well structured, carefully edited paragraphs (or short essay)

Weight: $10 \%$ each (60\% total)

Due: Week 2 (Beauty and the Beast), 4 (Aladdin), 6 (Rapunzel), 8 (Jack and the Beanstalk), 10 (The Little Mermaid), and 12 (The Snow Queen / Kai)

\section{Psychological Analysis}

In his book The Uses of Enchantment (1976), Bruno Bettelheim asserts the psychological value of fairy tales for children, and makes the case that these stories help young people to process their hopes and fears of such experiences as separation anxiety, oedipal conflict, and sibling rivalries. He argues that children need magic in order to experience vicarious satisfaction when they cannot achieve conscious recognition of their own inner conflicts. He argues that these stories externalize the internalized psychological conflicts of children; they delight and instruct, promoting psychological development and maturation. In this fairy tale, what desires, hopes and fears do the characters reveal? What psychological conflicts relevant to an audience of children are being externalized? How might the resolution presented in the fairy tale affect the development and maturation of an audience of children? Compare a traditional version of the tale with the Disney film version so popular with American children today as well as the biweekly, assigned film.

The Uses of Enchantment is available from the Internet Archive: https://archive.org/details/usesofenchantmen00brun

\section{Feminist Analysis}

Feminist re-tellings of traditional fairy tales have impacted the interpretation of fairy tales in the 20th and 21st centuries. Angela Carter's short story collection, The Bloody Chamber (1979), and Anne Sexton's poetry collection, Transformations (1971), are canonical feminist re-visions of fairy tales that explicitly critique themes of patriarchy (literally, "the rule of the father"), patriarchal ideology, oppression of women, cultural formation of gender roles (vs. biological sex), and unequal relationships between men and women while emphasizing the need for gender equality. In this fairy tale, how are patriarchal values established in the plot? Does the fairy tale reinforce or subversively undermine patriarchal ideology? How does feminist literary theory educate the reader about the underlying and interwoven meanings of the fairy tale? Compare a traditional version of the tale with a feminist re-telling by Carter or Sexton or another contemporary writer or filmmaker as well as the biweekly, assigned film.

The Bloody Chamber is available from the Internet Archive and the British Library: https://archive.org/details/bloodychambero00cart

https://web.archive.org/web/20160531193127/http://www.bl.uk/works/the-bloody-chamber-and-other-stories Transformations is available from the Internet Archive and ResearchGate (in The Complete Poems of Anne Sexton pp. 223-290):

https://archive.org/details/transformations00sext https://www.academia.edu/27872888/The_Complete_Poems_Anne_Sexton_WITH_A_FOREWORD_BY

\section{Audience Reception Analysis}

In his famous and influential essay, "On Fairy-stories" (given as the Andrew Lang Lecture at the University of St. Andrews in Scotland in 1939 and later published in 1947), J.R.R. Tolkien argues that fairy tales are primarily for adults, and that they provide an adult audience with four key things that we need: Fantasy, Recovery, Escape, and Consolation. Tolkien regards Fantasy as a high art in which human beings become sub-creators. He says, "Fantasy, the making or glimpsing of Other-worlds, was the heart of the desire of Faërie." For Tolkien, fairy tales allow adults to "recover" a clear view of reality by "escaping" from it, and the escape is not that of a deserter from the army, but of a prisoner from imprisonment. Consolation is found in the happy ending, the eucatastrophe, which is a sudden joyous turn of events in the plot that mirrors the Christian Gospel ("good news") that the end of all human suffering is salvation through Jesus and the culmination of history in heavenly places. How does this fairy tale promote fantasy, recovery, and escape for an adult audience? Is there a eucatastrophe in the story? Does the ending provide consolation to the reader, and if so, how so? Compare a traditional version of the tale to one aspect of the works of J.R.R. Tolkien, C.S. Lewis, or J.K. Rowling as well as the biweekly, assigned film. 
“On Fairy-stories" is available from WordPress: https://coolcalvary.files.wordpress.com/2018/10/on-fairy-stories1.pdf Grading Checklist for Fairy Tale Posts

Demonstrates knowledge of the plot, characters, settings, themes, and symbols of the fairy tale Analyzes the fairy tale in terms of psychological, feminist, or audience reception literary theory Compares a traditional version of the fairy tale to a modern retelling, such a Disney film, a feminist revision by Carter or Sexton, or a fantasy by J.R.R. Tolkien, C.S. Lewis, or J.K. Rowling Analyzes the adaptation of the fairy tale in the biweekly, assigned film Concludes with a question for peer response and responds to a peer's question in the online discussion forum $/ 10 \%$

\section{Copyrights}

Copyright for this article is retained by the author(s), with first publication rights granted to the journal.

This is an open-access article distributed under the terms and conditions of the Creative Commons Attribution license (http://creativecommons.org/licenses/by/4.0/). 